vocational training specialists, increasing the accessibility of education, meeting the needs of society in the amount of competitive professionals.

\title{
References:
}

1. Zakon Ukrainy «Pro Natsionalnu prohramu informatyzatsii», vid 13.09.2001 r. № 74/98-VR [Law of Ukraine «On National Informatzation Program» of 13.09.2001. no. $74 / 98-V R]$.

2. Ukaz prezydenta Ukrainy «Natsionalna stratehiia rozvytku osvity v Ukraini na 2012-2020 roky», vid 25.06.2013 № 344/2013 [Decree of the President of Ukraine «National Strategy of the Education Development in Ukraine for 2012-2020» of 25.06.2013 no. № 344/2013]

3. Poiasok, T. B. (2009). Systema zastosuvannia informatsiinykh tekhnolohii u profesiinii pidhotovtsi maibutnikh ekonomistiv: monohrafiia [System of informational technologies usage in professional preparation of future economists in higher educational establishments] (Manuscript of PhD Thesis), Kremenchuk : PE Shcherbatykh O. V.

4. Syrotenko, L. A. (2019). Ekonomichna pidhotovka maibutnikh pedahohiv profesiinoho navchannia zasobamy IKT [Economic training of future vocational training teachers by ICT means]. Pedagogy of formation of creative personality in higher and secondary schools, vol. 66, part 2, pp. 112-115.

\section{WEBINAR AS AN EFFECTIVE METHOD FOR DEVELOPING INFORMATION AND DIGITAL COMPETENCE OF SECONDARY SCHOOL STUDENTS}

\author{
Iana Topolnyk ${ }^{1}$ \\ Larysa Dzyna ${ }^{2}$
}

DOI: https://doi.org/10.30525/978-9934-588-39-6-15

Problem-search methods that contribute to the successful organization of the search, cognitive, creative activity of secondary school students are implemented through forms of project activity, web-quest, webinar, visualization methods and creation of e-portfolio - methods that require active use of information and communication technologies.

Let's take a closer look at the webinar, which is now seen as a tool that creates unique prerequisites for developing key competencies (including

\footnotetext{
${ }^{1}$ State Higher Educational Establishment «Donbas State Pedagogical univeRsity», Ukraine

${ }^{2}$ Bakhmut Comprehensive School Grades I-III № 10 of the

Bakhmut City Council Donetsk region, Ukraine
} 
information and digital), secondary school student independence in grasping the new, stimulating his natural curiosity and creativity.

Webinar is a technology that provides interactive learning activities in synchronous mode and provides tools for remote collaboration of participants [4]; is a kind of web conferencing, a form of online meetings or presentations by the Internet in real time.

Domestic and foreign scientists (V. Babiychuk [1], A. Kocharian [4], V. Kukharenko [5], T. Muller and M. Murdoch [6], J. Doyle, H. Farley and M. Keppell [3], who study various aspects of organizing, conducting webinars and implementing them in educational process of educational institutions, note the high popularity of this method.

$\mathrm{N}$. Volkova notes the typical characteristics of the webinar, among them:

- slide presentations;

- real-time video;

- audio communication through a computer in real time using audio equipment;

- an electronic comment board where the presenter and listeners can mark or comment on slide presentation points;

- text chat - for real-time Q\&A sessions for conference participants, both group chat (message visible to all participants) and private communication (conversation between two participants) are possible;

- voting and polling (allowing the presenter to poll the audience, providing several choices of answers) [2, p. 176-177].

Organizing and conducting a webinar requires the installation of appropriate software. Participation in the webinar does not require additional software.

To conduct a webinar, it is advisable to familiarize yourself with the resources of the Internet (http://adobe.com/, http://webinar.ru/, http://webinar.name/, http://fastwebinar.ru/, http://webinar.ua/, http://webinary.biz/, http://speakto.ru/), determine the platform that will meet all requirements, register, configure the parameters of the virtual cabinet and invite listeners. The webinar invitation looks like an online link that takes the participant to a virtual office.

An important condition for conducting a webinar is to provide reliable feedback, dialogue, which will promote the development of information and digital competence, Internet communication skills. This uses real-time messaging programs.

According to A. Kocharian, L. Varchenko-Trotsenko, and N. Morze the interactivity of the webinar can be ensured by various methods:

- online survey of participants (at the beginning, during and after the webinar), which is conducted with the purpose of updating basic knowledge about the topic, generalizing the material and motivating participants to actively participate as a listener; participants' answers may be open or hidden to others; 
- visualization of the discussion using a presentation, a demonstration of a computer desktop and applications; webinar visualization can be done using the element «Board», which allows participants to share a portion of the screen where slides, images, diagrams or tables can also be placed;

- summarizing the content of the webinar: each participant can use preprepared notes during a webinar, for example, in Microsoft OneNote, or make notes directly during a webinar; it is possible to take these notes at the same time by all participants, whose actions will be automatically updated and will be available online for sharing;

- file sharing during collaboration with a certain level of permission (for viewing, for editing);

- webinar recording in.mp4 format, which makes it easy to view its contents in most players and publish it online at any time for re-mastering the material or analyzing the lesson [4].

Therefore, we consider it advisable to use webinars for training in distance or mixed education of secondary school students.

\section{References:}

1. Babiichuk, V. H. (2010). Dystantsiina forma pidvyshchennia kvalifikatsii: struktura, zmist i zabezpechennia [Distance learning for advanced training: structure, content and provision]. September. Scientific-methodical information-educational journal, vol. 3-4, no. 52-53, pp. 63-75. Retrieved from: http://www.moippo.mk.ua/ attachments/article/160/Veresen_2010_3-4.pdf\#page=63 (accessed 17.06.2016).

2. Volkova, N. P. (2018). Interaktyvni tekhnolohii navchannia u vyshchii shkoli: navchalno-metodychnyi posibnyk [Interactive learning technologies in high school]. Dnipro: Universytet imeni Alfreda Nobelia. (in Ukrainian)

3. Doyle, J., Farley, H., Keppell, M., Cuthill, M., \& McDonald, L. (2014). Three good reasons to understand the research impact of a technology-enabled initiative. Proceedings of the 31st Australasian Society for Computers in Learning in Tertiary Education Conference (ASCILITE 2014): Rhetoric and Reality: Critical Perspectives on Educational Technology (New Zealand, Dunedin, 23-26 Nov. 2014).

4. Kocharian, A. B. (2016) Rozvytok informatsiino-komunikatsiinoi kompetentnosti naukovo-pedahohichnykh pratsivnykiv humanitarnykh spetsialnostei klasychnykh universytetiv [Development of information and communication competence of scientific and pedagogical workers of humanities specialties of classical universities] (PhD Thesis). Kyiv: In-t informatsiinykh tekhnolohii i zasobiv navchannia NAPN Ukrainy.

5. Kukharenko, V. M. (2011) Vykorystannia vebinariv u navchalnomu protsesi [Use of webinars in the educational process]. Computer at school and family, no. 2(90), pp. 12-16.

6. Muller, T., Murdoch, M. (2015). The Learning Explosion: 9 Rules to Ignite Your Virtual Classrooms. The Special Interactive Edition: Franklin Covey, 2015. Retrieved from: https://itunes.apple.com/us/book/learning-explosion-9-rules-to-igniteyour-virtual-classrooms/id960419837?mt=11 